\title{
農 薬の水系における動態
}

第 2 報＼cjkstart除草剂とダイアジノンの水系における消長

御嶎 初子・宮原 和夫" (佐賀県農業試験場・1佐賀県庁)

\begin{abstract}
Movement of pesticides in watercourse. 2. Fate of herbicides and diazinon in water following submerged application in paddy fields. Hatsuko MIKURIYA and Kazuo MiYahara ${ }^{11}$ (Saga Agricultural Experiment Station. Saga-gun, Saga 840-23. ${ }^{1}$ Saga Prefectural Government, Saga-gun, Saga 840-23)

The appearance of pesticide residues in paddy, irrigation, and creek water was monitored in Saga Agricultural Experiment Station, in 1981 for chlormethoxynil, CNP (chlornitrofen), oxadiazon and pyrazolate, and in 1983 for CNP, simetryn, oxadiazon and diazinon. When the precipitation was low, $20 \%$ of diazinon, $3 \%$ of simetryn and $0.05 \%$ of benthiocarb, CNP, and chlormethoxynil applied on paddy fields were estimated to reach the water. When the precipitation exceeded $70 \mathrm{~mm}, 3 \%$ of oxadiazon and pyrazolate applied on paddy fields was recovered in the water.
\end{abstract}

筆者等（御厨・宮原，1983）は，水田地帯のクリーク 水中の農薬の濃度消長を調査した結果, 粉剂で散布され る殺菌, 殺虫剤に比䡈し, 除草剂の水系における濃度が 高くなることを報告した。すなわち，除草戍は殺菌，殺 虫剤に比べて10 a当りの投下成分量が多く，しかも，水 を満たした水田に施用されるため，水系への流出が多く なると考えられる。ここでは，水田に施用された除草用 を主体に一部粒剂で使用される殺虫剂についてほ場排水 路水，クリーク水中の残留量を調查して，農薬の使用害 態，水利状況，気象条件などとの関連を解し，クリーク への農薬の流出量を推定すると共に, 農薬の田面水, 排 水路水, クリーク水での減少状況を検討したので，その 概要を報告する。

\section{調查方法}

\section{1. 農薬の施用方法および施用時期}

農試場内の水田 $8 \mathrm{ha}$ に粒剂は $10 \mathrm{a}$ 当り $3 \mathrm{~kg}$ を散粒機 で散布し，乳剤は $10 \mathrm{a}$ 当り $500 \mathrm{~m} l$ を均一に散布した。主 な施用日時と施用農薬および分析成分は，第1表のとお りである。オキサジアゾン，クロメトキシニル，CNP 単剤は移植前の代かき時に，ピラゾレート剤は移植 3 日 後に, ベンチオカーブ・CNP 剤は移植 7 日後に、シメ トリン・MCPB 剂は移植15日後に主に施用した。ダイ アジノンは 8 月上旬に施用した。移植は，6月20 24日 に本ほ場水田の $90 \%$ 以上で行われた。

\section{2. 試料採取方法}

採水は, 第 1 図に示した水田 2 地点, 排水路 4 地点,

第 1 表 農試水田に施用した主な農薬の成分量と主な施用時期および投下量に対する流出割合

\begin{tabular}{|c|c|c|c|c|c|c|}
\hline \multirow{2}{*}{ 主な施用時期 } & \multirow{2}{*}{ 農 } & \multirow{2}{*}{ 施用面積 } & \multirow{2}{*}{ 分 析 成 分 } & \multirow{2}{*}{ 投下成分量 } & \multicolumn{2}{|c|}{ 投下量に对する流出割合 } \\
\hline & & & & & 排水路 & クリーク \\
\hline 1981年 6 月17日 & クロメトキシニル粒剤 & 3.1ha & クロメトキシニル & $5954 \mathrm{~g}$ & $0.17 \%$ & $0.06 \%$ \\
\hline 6 月18日 & オキサジアゾン乳剂 & 1.8 & オキサジアソン & 1074 & 0.59 & 2.5 \\
\hline 6 月24日 & ピラゾレート粒剤 & 2.3 & ピラソレート & 5955 & 0.22 & 3.4 \\
\hline \multirow[t]{2}{*}{7 月 1 日 } & ベンチオカーブ・CNP粒剤 & 3.4 & ベンチオカーブ & 7368 & 0.13 & 0.07 \\
\hline & & & $\mathrm{CNP}$ & 5904 & 0.01 & 0.05 \\
\hline 1983年 6 月15日 & オキサジアソン乳剂 & 2.2 & オキサジアゾン & 1320 & 0.16 & 0.6 \\
\hline 6 月 15 日 & CNP 粒剂 & 1.5 & & & & \\
\hline 6 月 25 日 & ベンチオカーブ・CNP粒剂 & 2.0 & $\mathrm{CNP}$ & 6450 & 0.74 & 0.6 \\
\hline 7 月 9 日 & シメトリン・MCPB粒剤 & 3.0 & シメトリン & 1350 & 5.6 & 4.8 \\
\hline 8 月 5 日 & ダイアジノン 粒郕 & 0.6 & タイアジノン & 90 & 5.9 & 19.2 \\
\hline
\end{tabular}




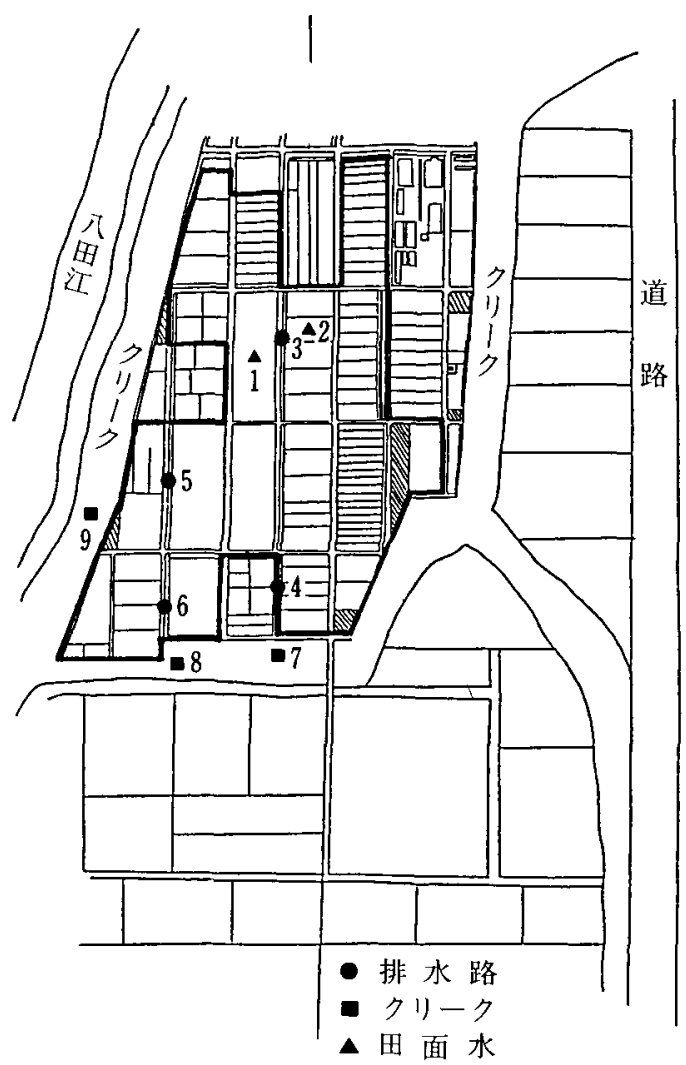

第 1 図採水地点

クリーク 3 地点の他に，コンクリート枠水田 $\left(4 \mathrm{~m}^{2}\right) 2$ 地点で, 1981 年は 5 月 29 日から翌年 2 月 3 日までの 12 回，1983年は施用前日，当日，1，3，7，14日後に行 った。クリーク水はクリーク中央の水面下 $20 \mathrm{~cm}$ の深さか ら, 排水路水は排水路の中央の水面下 $20 \mathrm{~cm} の$ 深さから, 田面水はほ場 4 力所から, $100 \mathrm{ml}$ のビーカーを用いて, ごみや土壤粒子が混入しないように 1 をを採水し，直ち に抽出濃縮を行った。

\section{3. 分析方法}

採取した水 1 に にジクロロメタン $150 \mathrm{ml}$ を加え, 2 回 抽出をくり返した後, 脱水濃樎し,アセトンで定容とし た。シメトリン, ベンチオカーブ, ダイアジノンは FPD-GC, オキサジアゾン, クロメトキシニル，ピラソ レート, CNP は ECD-GC で測定した。

\section{4. 水利状況}

農試の用水は，クリークよりポンプ揚水され，地下配 管によって水田にかんがいされている。排水は，水田か ら排水路へ，更に，大雨等で排水路が渵水となった時 は，排水路（第 1 図，No. 4) 功ポンプを用いてク リークへ汲み出されている。平常の場合は, 排水路とク
リークとの間にある制水門は少し開けてある。クリーク の採水地点は，制水門のある場所で，そこは農試の排水 路からの排水が主で, 周辺ほ場からの農薬の影響は少な いと思われる。

5. 気象状況

降水量については佐賀地方気象台の資料を利用した。 結果および考察

\section{I．農薬の水系における消長}

1981年, 1983年の調査各地点における農薬の最高濃度 を第 2 表に示した。クリーク水中で濃度の高かった農薬 は，1981年ではピラゾレート18ppb に次いで，オキサ ジアソン 8.1ppbで, 1983 年ではシメトリン $20 \mathrm{ppb}$, CNP 6.2ppb に次いで，ダイアジノン3.2ppbであった。 ベンチオカーブおよびクロメトキシニルの濃度は $1 \mathrm{ppb}$ 以下と低かった。1981年の各調査地点における農薬の平 均濃度を第 3 表に示した。この年には年間を通じて調査 を行い,ピークの時期を調查した。その結果, 排水路水 中では，クロメトキシニルは 6 月下旬に平均濃度 $10 \mathrm{ppb}$ 検出されたが，その後急速に減少し，8月上旬に検出限 界 $(0.1 \mathrm{ppb})$ 以下となったが，9月下旬と11月中旬に 再び検出された。オキサジアゾンは，7月中旬に $3 \mathrm{ppb}$ 検出され，その後徐々に濃度が低下したが，翌年 2 月に も $0.2 \mathrm{ppb}$ 検出された。ピラゾレートは 6 月下旬に 21 $\mathrm{ppb}$ 検出されたが，7月上旬には検出限界 $(2 \mathrm{ppb})$ 以下 となった。ベンチオカーブは 7 月上旬に $10 \mathrm{ppb}$ 検出さ れ，8月中旬には検出限界 $(0.2 \mathrm{ppb})$ 以下となった。 CNPは 6 月中旬に $2 \mathrm{ppb}$ 検出されたが,その後濃度は 低下し，8月中句には検出限界 $(0.1 \mathrm{ppb})$ 以下になっ た。9月下旬に濃度はやや高まったが，その後は 0 . $1 \mathrm{ppb}$ 以下であった。クロメトキシニル，CNP が9月下 旬に再び検出されたのは水田土壤から溶出したと考えら れる。1981年のクリーク水中の濃度消長は, クロメトキ シニルは 6 月下旬に0.3 ppb 検出されたが, 7 月上旬に は検出限界 $(0.1 \mathrm{ppb})$ 以下となり, クリーク水への流 出は極めて少なかった。オキサジアソンは 6 月中旬に 6 $\mathrm{ppb}$ 検出されたが，7月中旬には検出限界 (0.1ppb) 以下となった。しかし，8月上旬および 9 月下旬に低い 濃度であるが再び検出された。ピラゾレートは 6 月下旬 に $8 \mathrm{ppb} ， 7$ 月上旬には $13 \mathrm{ppb}$ と最も平均濃度が高くな ったが，8月中旬には検出限界 $(2 \mathrm{ppb})$ 以下となっ t。

1983年度は農薬施用後の諸水中の平均濃度を释時的に 調査した（第 4 表）。クリーク水中の消長は，オキサジ アゾンは 3 日後に0.8ppbと濃度が最も高くなったが, 
第 2 表各調査地点における農薬の最高濃度

\begin{tabular}{|c|c|c|c|c|c|c|c|c|c|c|c|}
\hline \multirow{3}{*}{ 年度 } & \multirow{3}{*}{ 農 薬 名 } & \multicolumn{5}{|c|}{ 濃 } & \multirow{2}{*}{\multicolumn{2}{|c|}{ 度 $\quad(\mathrm{ppb})$}} & \multirow{2}{*}{\multicolumn{3}{|c|}{ クリーク水 }} \\
\hline & & 田 & 面 & 水 & 排 & 水 & & & & & \\
\hline & & 1 & 2 & $\begin{array}{l}\text { コンクリート } \\
\text { 势水田 }\end{array}$ & 3 & 4 & 5 & 6 & 7 & 8 & 9 \\
\hline \multirow{5}{*}{ 1981年 } & ベンチオカーブ & $\begin{array}{c}30 \\
(3 \text { 日後) }\end{array}$ & & & 4.0 & 13 & 7.5 & 11 & 0.6 & 0.5 & 0.4 \\
\hline & CNP & $\begin{array}{c}20 \\
(3 \text { 日後 })\end{array}$ & & & 0.9 & 0.6 & 1.3 & 0.3 & 0.1 & 0.1 & 0.5 \\
\hline & オキサジアゾン & & $\begin{array}{c}79 \\
(1 \text { 日後) }\end{array}$ & & 2.7 & 4.3 & 2.9 & 2.0 & 8.1 & 6.4 & 7.2 \\
\hline & クロメトキシニル & $\begin{array}{c}20 \\
(7 \text { 日後) }\end{array}$ & & & 11 & 10 & 6.1 & 8.4 & 0.2 & 1.0 & 0.2 \\
\hline & ピラゾレート & & $\begin{array}{r}550 \\
\text { (当日) }\end{array}$ & & 36 & 27 & 4.0 & 21 & 18 & 16 & 13 \\
\hline \multirow{4}{*}{ 1983年 } & オキサジアゾン & $\begin{array}{r}32 \\
\text { (当日) }\end{array}$ & & $\begin{array}{r}28 \\
\text { (当日) }\end{array}$ & $\begin{array}{r}3.7 \\
\text { (当日) }\end{array}$ & $\begin{array}{c}2.6 \\
(3 \text { 日後) }\end{array}$ & $\begin{array}{c}2.1 \\
(1 \text { 日後) }\end{array}$ & $\begin{array}{c}1.1 \\
(3 \text { 日後 })\end{array}$ & $\begin{array}{c}0.2 \\
(1 \text { 日後) }\end{array}$ & $\begin{array}{c}0.9 \\
(3 \text { 日後) }\end{array}$ & $\begin{array}{c}1.4 \\
(3 \text { 日後) }\end{array}$ \\
\hline & $\mathrm{CNP}$ & & $\begin{array}{r}88 \\
\text { (当日) }\end{array}$ & $\begin{array}{r}73 \\
\text { (当日) }\end{array}$ & $\begin{array}{c}10 \\
(1 \text { 日後) }\end{array}$ & (1 ${ }^{73}$ 日後) & $\stackrel{55}{(1 \text { 日後) }}$ & $(1$ 日後) & $\begin{array}{c}1.0 \\
\text { (1 日後) }\end{array}$ & $\begin{array}{c}3.5 \\
\text { (1 日後) }\end{array}$ & $\begin{array}{c}6.2 \\
\text { (1 日後) }\end{array}$ \\
\hline & シメトリン & $\begin{array}{c}410 \\
(1 \text { 日後) }\end{array}$ & (1 $\begin{array}{c}250 \\
\text { 日後) }\end{array}$ & $\begin{array}{r}520 \\
\text { (当日) }\end{array}$ & (1 ${ }^{41}$ 日後) & $\begin{array}{l}140 \\
\text { (当日) }\end{array}$ & ( 1 日後) & $\begin{array}{c}62 \\
\text { （当日） }\end{array}$ & $\begin{array}{c}4.6 \\
(1 \text { 日後) }\end{array}$ & $\begin{array}{c}7.2 \\
\text { (1 日後) }\end{array}$ & $\begin{array}{c}20 \\
\text { (1 日後) }\end{array}$ \\
\hline & タイアジノン & $\begin{array}{c}3,600 \\
(1 \text { 日後) }\end{array}$ & $\begin{array}{c}1,900 \\
(1 \text { 日後) }\end{array}$ & $\begin{array}{c}2.300 \\
(1 \text { 日後) }\end{array}$ & $\begin{array}{c}20 \\
(3 \text { 日後) }\end{array}$ & $\begin{array}{r}0.6 \\
\text { (当日) }\end{array}$ & $\begin{array}{r}0.5 \\
\text { (当日) }\end{array}$ & $\begin{array}{r}0.4 \\
\text { (当日) }\end{array}$ & $\begin{array}{r}3.2 \\
\text { (当日) }\end{array}$ & $\begin{array}{r}0.7 \\
\text { (当日) }\end{array}$ & $\begin{array}{r}1.5 \\
\text { (当日) }\end{array}$ \\
\hline
\end{tabular}

注：（）内は経過日数，1，2，コンクリート梊水田は 2 カ所の平均值

第 3 表 1981年の各調查地点における農薬の平均浱度

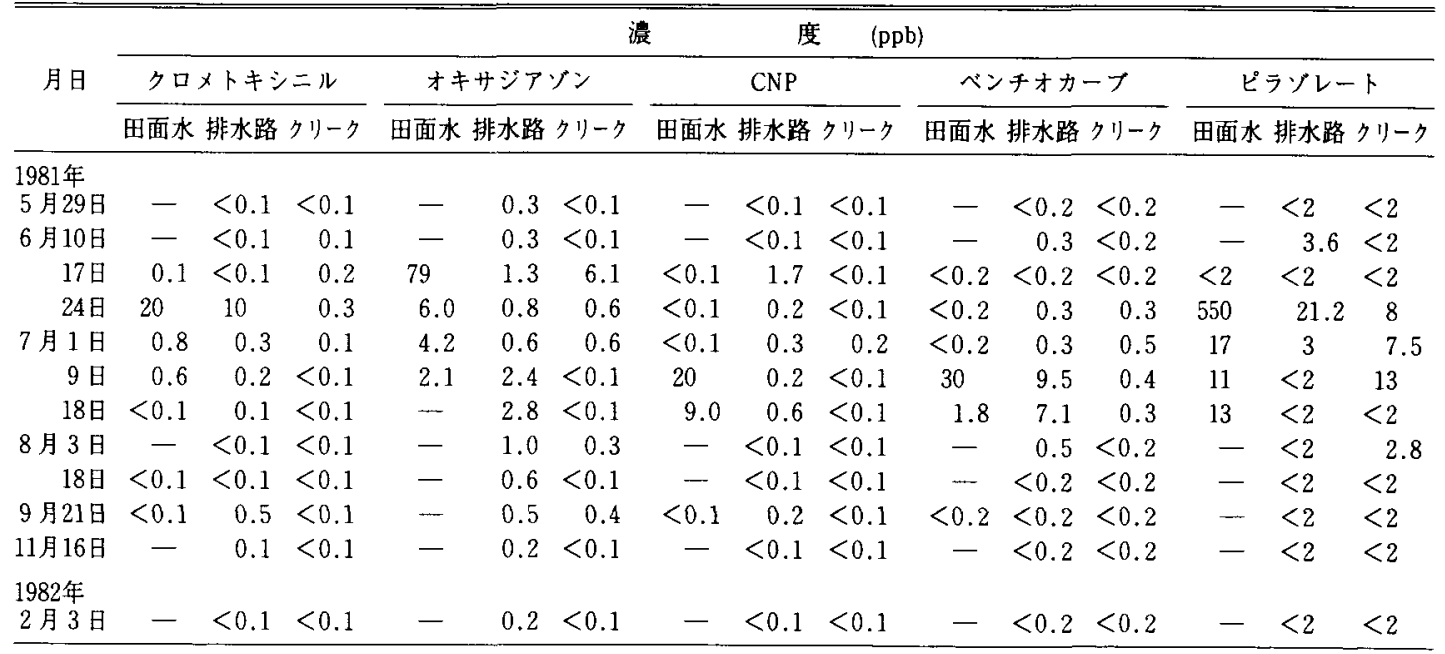

第 4 表 1983年の各調查地点における調査農薬の平均濃度

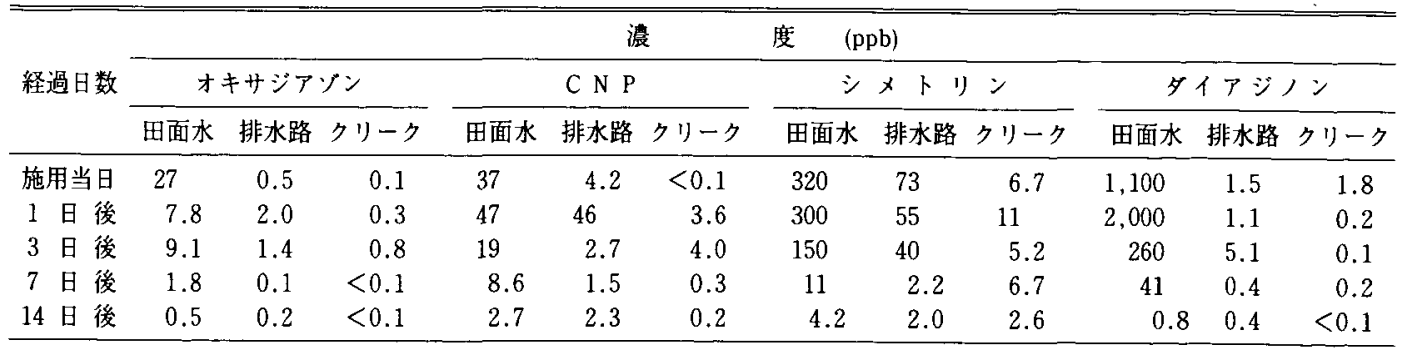


7 日後には検出限界 $(0.1 \mathrm{ppb})$ 以下に減少した。CNP は 3 日後に $4 \mathrm{ppb}$ と最も高い濃度で検出されたが，7 日後には $0.3 \mathrm{ppb}$ と減少した。シメトリンは 1 日後に $11 \mathrm{ppb}$ と最も濃度が高くなり，14日後でも2.6ppbと， 他の農薬に比べ，ゆやかに減少した。ダイアジノンは 除草哓に比べ施用量が少なかったため, 当日 $1.8 \mathrm{ppb}$ 検 出されたものの, その後は検出限界 $(0.1 \mathrm{ppb})$ 近くに 低下した。

以上のように，クリーク水中での濃度は，ピラゾレー

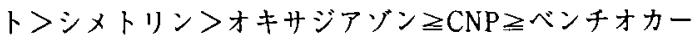
ブニダイアジノンの順に低下した。クリーク水中におけ る平均濃度の最高值をみると，ピラゾレート (13ppb) およびシメトリン (11ppb) で高く，オキサジアゾン $(6.1 \mathrm{ppb}), \mathrm{CNP}(4.0 \mathrm{ppb})$ と続くのに对し, ベンチオ カーブおよびダイアジノンは 1 ppb 以下であった。 CNP およびオキサジアゾンは調查年によって最高值は 大きく異なり,年によって $1 \mathrm{ppb}$ 以下の場合もあった (御厨・宮原，1983）。CNP，オキサジアゾンは，水溶性 が低いためクリーク水中への流出は少ないが，降雨や移 植作業のため，施用後 2 日以内に田面水から排出された 場合, 流出量が多くなり低濃度で長くクリーク水中で検 出される。

II . 農薬のクリータ水への流出量

両調査年における農試水田に施用した投下量に対する 排出路およびクリーク水への流出割合は前報の方法にし たがって行い(御征・宮原，1984），それを第 1 表に, 日別降水量を第 5 表に示した。コンクリート枠水田で降 水量と農薬の流出量を検討した結果，施用後 2 日間の降
水量が多い時に，流出量が多くなることがわかった。水 田投下量に対する排水路水への流出量の割合は, シメト リンおよびダイアジノンでは，施用 2 日後まで降水量は ほとんどなかったが，約 $6 \%$ と高かった。また，施用 2 日後降水量が少なかった CNP, ベンチオカーブおよび クロメトキシニルの場合は, 排水路への流出量は投下成 分量の $0.2 \%$ 以下と推定された。一方, 施用後の降水量 の多かったオキサジアゾン，ピラゾレートおよび CNP の場合は，流出量は投下量の $1 \%$ 以下と推定された。ク リーク水への流出割合はダイアジノンが施用後の降水量 が少なかったにもかかわらず19\%と最も高く，次いで同 様な条件で施用されたシメトリンが $5 \%$ と高い值を示し た。施用後 2 日間の降水量が $70 \mathrm{~mm}$ 以上のオキサジアゾン 拈よびピラゾレートの場合は約 $3 \%$ ，降水量の少なかっ たベンチオカーブ，クロメトキシニルおよび CNP の場 合は約 $0.05 \%$ 流出したと推定できた。埼玉県（中村， 1982），神奈川県（飯塚・岩無，1982），滋賀県（中村ら， 1982), 千葉県 (丸, 1983), 秋田県 (山谷, 1983) での 河川や用水排水路への流出量は, CNP 0.1 13.5\%, ベ ンチオカーブ $2 \sim 4.3 \%$ ，オキサジアゾン $38 \%$ ，シメト リン $2 \sim 60.5 \%$ あるのに対して，前述したように，佐 賀県でのクリーク水中への流出割合は極めて低加った。 この原因として，微生物による農薬分解力の差が考えら れるので，さらに検討をしたい。しかし，本県では，ク リーク水を循環して使用しており，また，除草剤施用時 期は梅雨期に当たることから，施用 2 日間の降水量によ ってクリークへの流出量が多くなることが推定され，除

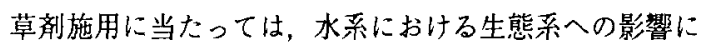

第 5 表 1981年, 1982年の降水量と農薬の主な施用日

\begin{tabular}{|c|c|c|c|c|c|c|c|c|c|}
\hline \multirow{2}{*}{ 月日 } & \multicolumn{2}{|r|}{ 1981年 } & \multicolumn{2}{|r|}{ 1983年 } & \multirow{2}{*}{ 月日 } & \multicolumn{2}{|r|}{ 1981年 } & \multicolumn{2}{|c|}{ 1983年 } \\
\hline & 降水量mm & 施用農薬 & 降水量mm & 施用農薬 & & 降水量mm & 施用農薬 & 降水量mm & 施用農薬 \\
\hline 6.15 & - & & 33.5 & $\underset{\mathrm{CNP}}{\text { オキサジアソン }}$ & 7. 1 & 0.5 & $\begin{array}{c}\text { ベンチオカーフ } \\
\text { CNP }\end{array}$ & 0.0 & \\
\hline 16 & 0.0 & & 29.0 & & 2 & 1.0 & & 2.5 & \\
\hline 17 & 1.0 & クロメトキシニル & 0.0 & & 3 & 21.5 & & 3.0 & \\
\hline 18 & 0.5 & オキサジアゾン & - & & 4 & 2.0 & & 15.0 & \\
\hline 19 & 0.0 & & 29.0 & & 5 & - & & 75.5 & \\
\hline 20 & 75.5 & & 118.0 & & 6 & - & & - & \\
\hline 21 & 4.5 & & 3.0 & & 7 & 59.5 & & 0.5 & \\
\hline 22 & 11.0 & . & - & & 8 & 8.0 & & - & \\
\hline 23 & 0.0 & & 2.5 & & 9 & 0.0 & & - & シメトリン \\
\hline 24 & 0.0 & ピラソレート & 5.0 & & 10 & 49.0 & & - & \\
\hline 25 & 32.0 & & - & CNP & 11 & - & & - & \\
\hline 26 & 72.0 & & 23.0 & & 12 & 0.0 & & - & \\
\hline 27 & 54.0 & & 11.0 & & 13 & 4.0 & & - & \\
\hline 28 & 1.5 & & 0.5 & & 14 & 0.0 & & 1.0 & \\
\hline 29 & 34.5 & & 0.0 & & 15 & 0.0 & & 41.5 & \\
\hline 30 & 122.5 & & - & & & & & & \\
\hline
\end{tabular}


第 6 表 1983年の調查結果にもとづき求めた農薬の半減期と濃度一経過日数の相関係数 $\left(\log C=\log \mathrm{Co}_{0}-\mathrm{Kt}\right)$

\begin{tabular}{|c|c|c|c|c|}
\hline & 田 & 面 & \multirow{2}{*}{ 水 路 水 } & \multirow{2}{*}{ クリ 一轻 } \\
\hline 吕 & 直 & コンクリート桿水田 & & \\
\hline オキサジアソン & $\begin{array}{c}2.1 \text { 日 } \\
(-0.921)\end{array}$ & $\begin{array}{c}2.5 \text { 日 } \\
(-0.976)\end{array}$ & $\begin{array}{c}4.7 \text { 日 } \\
(-0.510)\end{array}$ & $\begin{array}{c}10.7 \\
(-0.296)\end{array}$ \\
\hline $\mathrm{C} \quad \mathrm{N} \quad \mathrm{P}$ & & $\begin{array}{c}2.4 \\
(-0.974)\end{array}$ & $\begin{array}{c}7.5 \\
(-0.443)\end{array}$ & $\begin{array}{c}5.5 \\
(-0.376)\end{array}$ \\
\hline シメトリン & $\begin{array}{c}2.9 \\
(-0.907)\end{array}$ & $\begin{array}{c}2.3 \\
(-0.899)\end{array}$ & $\begin{array}{c}3.0 \\
(-0.842)\end{array}$ & $\begin{array}{c}11.2 \\
(-0.596)\end{array}$ \\
\hline ダイアシンン & $\begin{array}{c}1.2 \\
(-0.905)\end{array}$ & $\begin{array}{c}1.1 \\
(-0.844)\end{array}$ & $\begin{array}{c}12.1 \\
(-0.472)\end{array}$ & $\begin{array}{c}7.1 \\
(-0.565)\end{array}$ \\
\hline
\end{tabular}

（）内は相関係数

第 7 表 围場およびコンクリート枠田面水における農薬隇衰式の減衰定数（ $\log C=\log \mathrm{C}_{0}$-KtにおけるKの値）

\begin{tabular}{|c|c|c|c|c|c|c|}
\hline \multirow{2}{*}{ 農 } & \multirow{2}{*}{$\frac{50 \mathrm{a}}{\mathrm{A}}$} & \multirow{2}{*}{$\frac{\text { 場 }}{\mathrm{B}}$} & \multirow{2}{*}{$10 \mathrm{a}$} & \multicolumn{2}{|c|}{ コンクリート枠水田 $\left(4 \mathrm{~m}^{2}\right)$} & \multirow{2}{*}{ 平 } \\
\hline & & & & A & B & \\
\hline オキサジアゾン & 0.132 & 0.142 & - & 0.139 & 0.110 & 0.131 \\
\hline $\mathrm{C} \quad \mathrm{N} \quad \mathrm{P}$ & - & - & - & 0.135 & 0.121 & - \\
\hline シメトリン & 0.132 & 0.137 & 0.072 & 0.184 & 0.182 & 0.141 \\
\hline ダイアジノン & 0.240 & 0.253 & 0.252 & 0.250 & 0.289 & 0.257 \\
\hline
\end{tabular}

ついて十分注意していく必要がある。

III. 農薬の水系に扔ける減衰式

農薬施用後, 経時的に残留量を測定した1983年の結果 にもとづき, 農薬の半滅期と濃度-経過日数の相関係数 を求め, 第 6 表に示した。減衰式 $\log \mathrm{C}=\log \mathrm{Co}-\mathrm{Kt}$ $\left(\log \mathrm{C}\right.$ : 施用 $\mathrm{t}$ 日後の推定濃度, $\log \mathrm{C}_{0}$ : 最高濃度, $\mathrm{K}$ : 定数, $\mathrm{t}$ : 経過日数) の適合度は, 田面水では高かった が, 排水路, クリーク水では低く，適合しなかった。田 面水における半隇期は, ほ場とコンクリート枠水田 $\left(4 \mathrm{~m}^{2}\right)$ 間に大きな差はなく, シメトリン $=\mathrm{CNP}=$ 才 キサジアゾン（約2.5日）>ダイアジノン（約1.2日）で あった。排水路, クリーク水については, 二次式, 三次 式等についても検討したが，適合するものがなく，より 詳しい経時的な調查が必要と思われる。式 $\log C=\log$ $\mathrm{C}_{0}$ - Kt に適合した田面水についての K 值を第 7 表 に示した。Kの值は，同じ農薬を同じ時期に施用した場 合は，ほ場の一般的な水管理，ほ場の大きさ（50 a ある いは10 a ) やコンクリート枠水田 $\left(4 \mathrm{~m}^{2}\right)$ の使用によっ ても大きな差を示さなかった。その值は, ダイアジノン (0.257) >シメトリン $(0.141)$ >オキサジアゾン $(0$. 131）> CNP (0.128) の順に小さくなった。

要 約

農試水田 8 ha に1981年にベンチオカーブ, CNP，ク ロメトキシニル，ピラゾレートおよびオキサジアゾンを 施用し，その排水路および周辺のクリーク中の残留農薬 の濃度を調查した。1983年はさらにオキサジアゾン，
CNP，シメトリン，ダイアジノンを施用し，残留量を経 時的に調查して，水系への流出量および減衰式を求め た。

クリーク水への農薬の流出量は, 施用後 2 日間の降水 量が70m以上の場合多くなった。水田投下成分量に対す るクリーク水への流出量の割合は, 降雨の少なかった時 に施用したダイアジノンでは約 $20 \%$ と最も高く，同様な 場合のシメトリンでも約 $5 \%$ と推定された。降水量が多 い時に施用したオキサジアゾンおよびピラゾレートでは 約 $3 \%$ ，降雨の少ない時施用したベンチオカーブ，クロ メトキシニルおよび CNP では約 $0.05 \%$ と流出割合が推 定された。

農薬の水系における減衰式 $\log C=\log \mathrm{C}_{0}-\mathrm{Kt} （ \log \mathrm{C}$ : 施用 $\mathrm{t}$ 日後の推定濃度, $\log \mathrm{C}_{0}$ : 最高濃度, $\mathrm{K}$ : 定数, $\mathrm{t}$ : 経過日数）に対し，田面水での適合度は高かったが,排 水路水，クリーク水では適合しなかった。この式に適合 した田面水での $\mathrm{K} の$ 值は，同じ農薬を同じ時期に施用し た場合，ほ場の水管理，ほ場の広さやコンクリート枠水 田の使用によっても大きな差はなかった。

\section{引用 文 献}

1)飯塚宏栄・岩無才次郎 (1982) 用水と廃水 $24: 629$. 2）丸諭（1983）昭和58年度農薬水系環境動態調査研究報告書 千葉県. 3) 御缛初子・宮原和夫 (1983) 生態化学 6(2) :23-33. 4) 中村幸二 (1982) 植物防疫 $36: 251$. 5) 中村 - 小林・長谷川 (1982) 昭和 57 年農薬試験研究打合わせ会 議資料 25.6 6) 山谷正治 (1983) 昭和58年度農薬水系環境 動態調查研究報告書 秋田県. 